\title{
ASSESSMENT OF THE SCENE OF HOT CHOCOLATE GIRL FROM THE VIEWPOINT OF DYNAMIC EQUILIBRIUM ACCORDING TO JEAN-ETIENNE LIOTARD'S PICTURE „LA BELLE CHOCOLATIÈRE“
}

Eliava G.G. ${ }^{1}$, Tsintsadze T.G. ${ }^{2}$, Kasradze P.A. ${ }^{3}$, Svanishvili T.R. ${ }^{4}$, Buachidze T.Sh. ${ }^{5}$, Topuria L.S.6 (Georgia) Email: Eliava341@ scientifictext.ru

\author{
${ }^{1}$ Eliava Giorgi Grigorjevich - Doctor of biological sciences, Professor; \\ ${ }^{2}$ Tsintsadze Tamar Givievna - Candidate of medical sciences, Professor, Head of the Department, \\ DEPARTMENT OF PHARMACY, \\ GEORGIAN TECHNICAL UNIVERSITY; \\ ${ }^{3}$ Kasradze Pavel Aleksandrovich - Doctor of medicine, Head of the Department, \\ DEPARTMENT OF MEDICAL REHABILITATION AND SPORTS MEDICINE, \\ ACADEMICIAN N. KIPSHIDZE CENTRAL UNIVERSITY CLINIC; \\ ${ }^{4}$ Svanishvili Tamara Romanozovna - Candidate of medical sciences, Assistant, \\ DEPARTMENT OF SPORTS MEDICINE AND REHABILITATION, \\ TBILISI STATE MEDICINE UNIVERSITY; \\ ${ }^{5}$ Buachidze Teimuraz Shalvovich - Candidate of biological sciences, Professor; \\ ${ }^{6}$ Topuria Lela Sergeevna - Candidate of biological sciences, Associate Professor, \\ DEPARTMENT OF MEDICAL BIOENGINEERING \\ GEORGIAN TECHNICAL UNIVERSITY, \\ TBILISI, GEORGIA
}

\begin{abstract}
: assessment of the scene of hot chocolate girl from the viewpoint of dynamic equilibrium according to Austrian artist Jean-Etienne Liotard's picture „,La Belle Chocolatiere“ is considered in the work.

The history of manufacturing of materials of coffee cup and glass of cold water - subjects placed on brown varnished wooden Japanese tray held by the waitress, is examined. It can be said that there were high requirements for service in the environment, where a waitress is depicted according to artist's idea.

We offer a Georgian title of the picture in the form, which will be acceptable for Georgian-speaking readers based on picture's storyline and history.

From the perspective of anatomic assessment and motion biomechanics and based on analysis, there is drawn a conclusion that beautiful hot chocolate girl (waitress) is depicted not in the static equilibrium, but in position of dynamic equilibrium.

Besides, it should be noted that body posture of a waitress, predetermined by corresponding anatomic principles and characteristic harmonious picturesque dress is completely reflected in the image of beautiful waitress.

Thus, Jean-Etienne Liotard's picture shows us the expressed dynamic stereotype of a waitress, which along with outer beauty and characteristic harmonious picturesque dress of a chocolate girl reflects genre scene showing corresponding dynamic equilibrium and has positive impact on mood of human of any times and era.

Keywords: "La Belle Chocolatière», dynamic equilibrium, static equilibrium, common center of gravity.
\end{abstract}

\section{ОЦЕНКА СЦЕНЫ ШОКОЛАДНИЦЫ С ТОЧКИ ЗРЕНИЯ ВОСПРОИЗВЕДЕНИЯ ДИНАМИЧЕСКОГО РАВНОВЕСИЯ ПО КАРТИНЕ ЖАНА-ЭТЬЕНА ЛИОТАРА «LA BELLE CHOCOLATIÈRE» Элиава Г.Г. ${ }^{1}$, Цинцадзе Т.Г. ${ }^{2}$, Касрадзе П.А. ${ }^{3}$, Сванишвили Т.P. ${ }^{4}$, Топуриа Л.С. 5 (Грузия)}

\author{
${ }_{1}$ Элиава Георгий Григорьевич - доктор биологических наук, профессор; \\ ${ }^{2}$ Циниадзе Тамар Гивиевна - кандидат медииинских наук, профессор, руководитель департамента, \\ департамент фармачии, \\ Грузинский технический университет; \\ ${ }^{3}$ Касрадзе Павел Александрович - доктор медичины, профессор, руководитель департамента, \\ департамент медицинской реабилитации и спортивной медицины, \\ Центральная университетская клиника им. академика Н. Кипшидзе; \\ ${ }^{4}$ Сванишвили Тамара Романозовна - кандидат медицинских наук, ассистент, \\ департамент спортивной медицины и реабилитации, \\ Тбилисский государственный медииинский университет; \\ ${ }_{5}^{5}$ Буачидзе Теймураз Шалвович - кандидат биологических наук, профессор; \\ ${ }^{6}$ Топуриа Лела Сергеевна - кандидат биологических наук, ассоичированный профессор, \\ департамент медииинской биоинженерии, \\ Грузинский технический университет, \\ г. Тбилиси, Грузия
}


Аннотация: в работе дана оценка сцены шоколадниџы с точки зрения воспроизведения динамического равновесия по картине Жана-Этьена Лиотара «La Belle Chocolatière».

Рассмотрена история изготовления материала предметов, находящихся на коричневом лакированном деревянном японском подносе шоколадниць: чашки горячего шоколада и стакана с холодной водой. Можно отметить, что в той обстановке, в которой по замыслу художника изображена шоколадница, были высокие требования к обслуживанию.

Исходя из сюжета и истории картины, нами предложен такой вариант грузинского названия картинь, которое будет более приемлемым для грузиноязычного читателя.

Исходя из анатомической оценки и позиций биомеханики движений, на основе приведенного анализа мы пришли к заключению, что прекрасная служанка с горячим шоколадом изображена не в статическом равновесии, а в состоянии динамического равновесия.

Кроме этого, надо отметить, что привлекающая внимание представительность служанки, обусловленная соответствующей анатомической основой и характерным для служанки гармоничным, колоритным одеянием, полностью воплощается в образе обаятельной служанки.

Таким образом, Жан-Этьен Лиотар в своей картине передал выраженный динамический стереотип служанки, который наряду с ее внешней красотой отражает жанровую сцену с передачей динамического равновесия и оказывает позитивное влияние на настроение людей всех времен и эпох.

Ключевые слова: "La Belle Chocolatière» («Шоколадница»), динамическое равновесие, статическое равновесие, общий центр тяжести.

Adequate representation of human figure in different postures of human when in motion and when executing different functions by the depiction method is one of the most important tasks $[4,5,6,7]$.

As is known, motor action consists of several elements, which are combined with each other in one complete act.

Under conditions of waitress's work, as well as of representatives of other professions, differently passing motor reflexes are united in general chain of reactions, which is executed according to certain dynamic stereotype $[1,2,3]$.

Evaluation of waitress posture from the viewpoint of reflection of dynamic stereotype according to JeanEtienne Liotard's "La Belle Chocolatière" is considered in the work [9].

On the first figure the title of picture in French and German is given. For Georgian-speaking reader we tried to represent the title of picture in acceptable form, based on its storyline and history. This title gives the Georgian-speaking reader information in his mother tongue about the fact that a very good-looking waitress serving hot chocolate is shown in the picture.

The storyline of Jean-Etienne Liotard's picture is simple (Fig. 1): young, handsome German girl dressed as waitress is depicted in profile. She brings a cup of hot chocolate and a glass of water on the tray.

As far as the wares placed on the tray have their own history, we can consider their comparative assessment.

New hot chocolate is poured into a cup made of worldwide known Meissen porcelain. Porcelain manufactory Meissen (German porcelain brand) was founded in 1710, for the first time in Europe, subsequent to discovery of secret of solid porcelain's manufacturing in Saxony. It should be noted that image of one of the very first artistic representation of Meissen porcelain in pastel is depicted in the abovementioned picture of Jean-Etienne Liotard.

The material of glass tumbler is also noteworthy. Water is poured into a tumbler made of Bohemian glass.

Bohemian glass is a blown glass, which was manufactured in Czechia according to old traditions. For the first time it is mentioned in chronicles in 1162, and is one of the national prides of Czechs. Nowadays the cookware and accessories made of this material grace the interiors of hotels, canteens and restaurants.

Cookware made of above mentioned expensive materials is placed on a brown varnished Japanese tray. The trays of different forms (round, oval etc.) were manufactured in Japan. In this case Jean-Etienne Liotard shows us small-sized brown varnished rectangular Japanese tray, made of wood.

So, it can be said that in the environment, where the waitress is depicted according to artist's idea, there were high requirements for service: freshly made hot chocolate had to be served in precious plate - in a cup made of worldwide known Meissen porcelain, while a water for drinking afterwards was served by a tumbler manufactured from famous Bohemian glass.

According to the first picture one may mention that the chambermaid is lightened by imaginary light source (which is not represented in the picture), which forms girl's shadow. In this case it may be said that a light is fallen from above left side and reflects not only a waitress shown in profile but also the illumination around model at that moment that plays important role in perception of visual appeal of a chocolate girl.

As is seen from the picture (Fig. 1), a waitress stands almost against neutral background, which is emerged between light-colored wall and the floor.

The model's look directed down and items in her hand create the impression that a waitress is depicted not in static position, but as if she walks forward toward the table [10].

From the perspective of anatomic assessment and motion biomechanics [1,2,3,8], in "stand-at-ease" posture during static equilibrium the vertical of gravity passes in front of atlanto-occipital joint and spine, behind hip joint and in front of knee joint and ankle joints (Fig. 3). 
In case of static equilibrium of the body, the resulting force directed to common center of gravity is located at the level of second sacral vertebra and perpendicular dropped from common center of gravity is projected on bearing surface (Fig. 2a). Head and body are disposed on one straight line (Fig. 3). Vertical of gravity passes 2 $\mathrm{cm}$ before hip joint, 1,5 $\mathrm{cm}$ before knee joint and 2,5 $\mathrm{cm}$ before ankle joint [3].

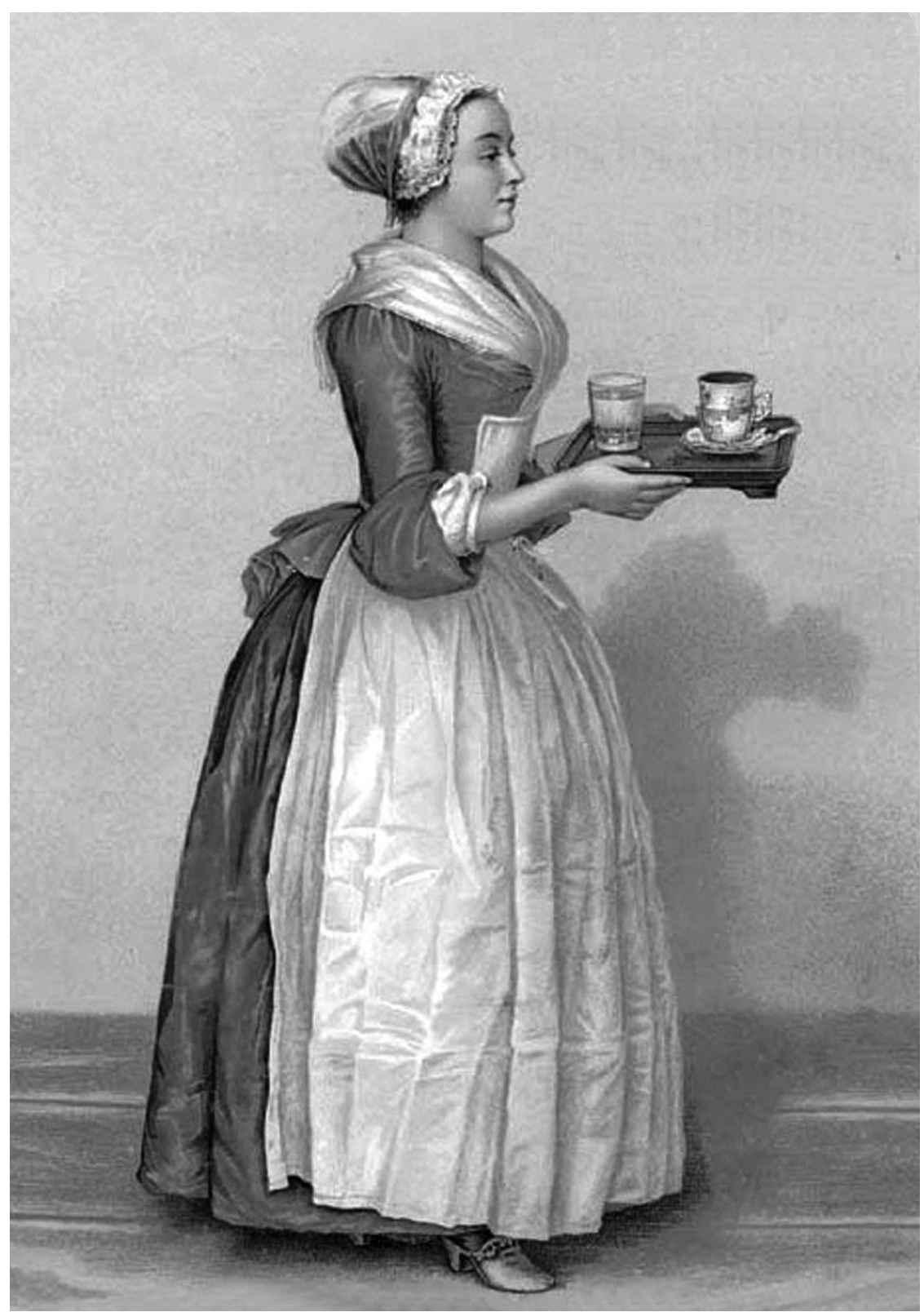

Fig. 1. La Belle Chocolatière, Das Schokoladenmädchen (circa 1743-1745)

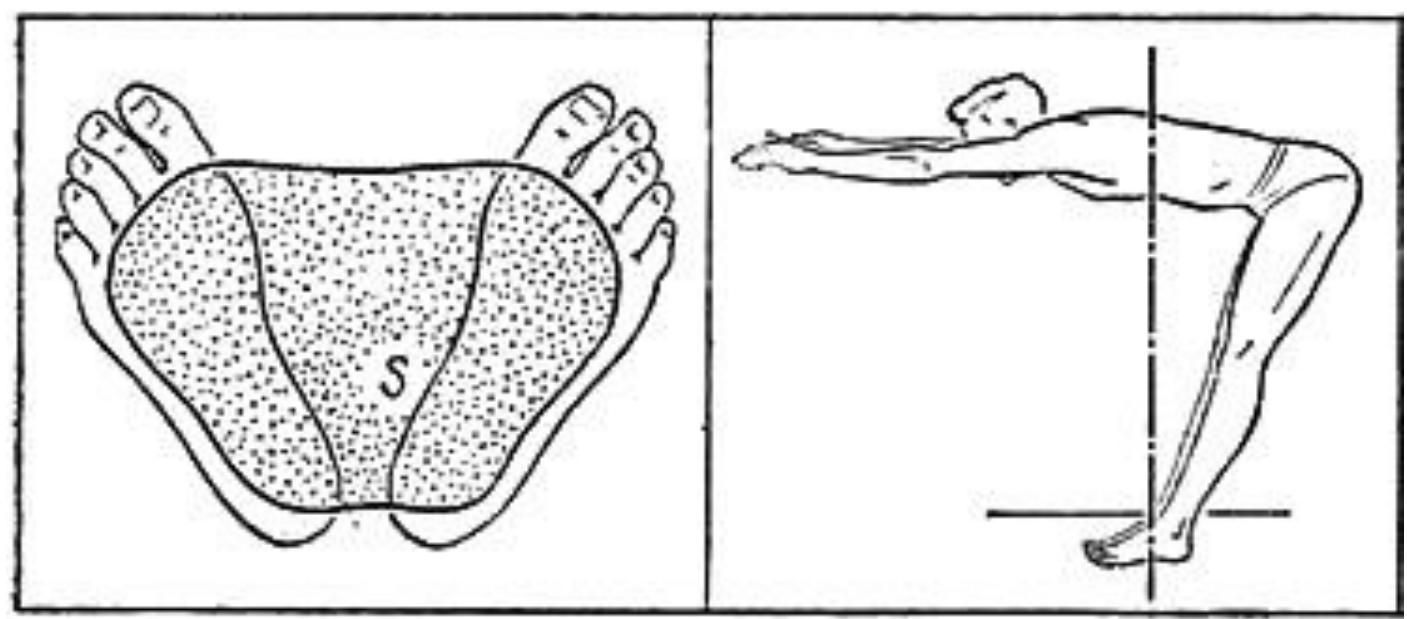


Fig. 2. Supporting plane of the body during stand-at-ease and body bent:

$a-S$-point at the supporting plane corresponds to projection of general center of gravity; $b$ - restoration of body balance

The circumstance that Jean-Etienne Liotard shows the waitress's picture in motion is confirmed by our analysis.

Restoration of equilibrium during bent forward is achieved through compensated change of muscle action. Vertical projection of the gravity center (vertical line) returns to initial position on support plane (Fig. 2b). So, body weight creates a static (rotation) moment of forces directed towards a whole range of joints: body force of gravity is focused at straightening of hip and knee joints, bending of ankle joints and bent forward of body etc.

Preservation of static equilibrium is possible in the moment when resulting rotation moment generated by body force of gravity and other external forces is opposed to counterbalance moment of internal (muscular) power, which is equal in magnitude but opposite in direction.

Taking into account the above mentioned and drawing imaginary vertical from waitress's head toward body (Fig. 1), we will come to conclusion that a head and body of the girl are not disposed on one vertical line and, therefore, one may say that waitress is not depicted in static equilibrium and she is not in stand-at-ease position.

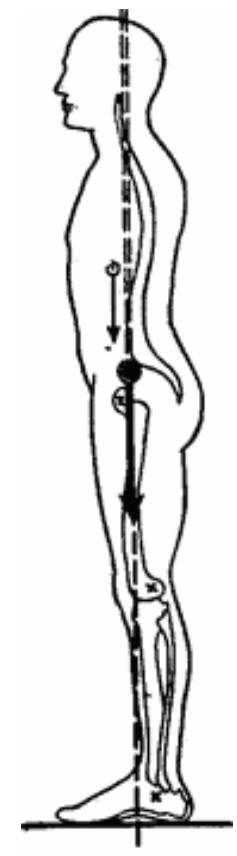

Fig. 3. Statical equilibrium of human during upright posture

In our opinion, a waitress depicted by Jean-Etienne Liotard is shown in dynamic equilibrium.

When walking, human body moves and he/she alternately leans on one leg after another (Fig. 4). At this time alternate shift of body center of gravity takes place and it is necessary to restore equilibrium.

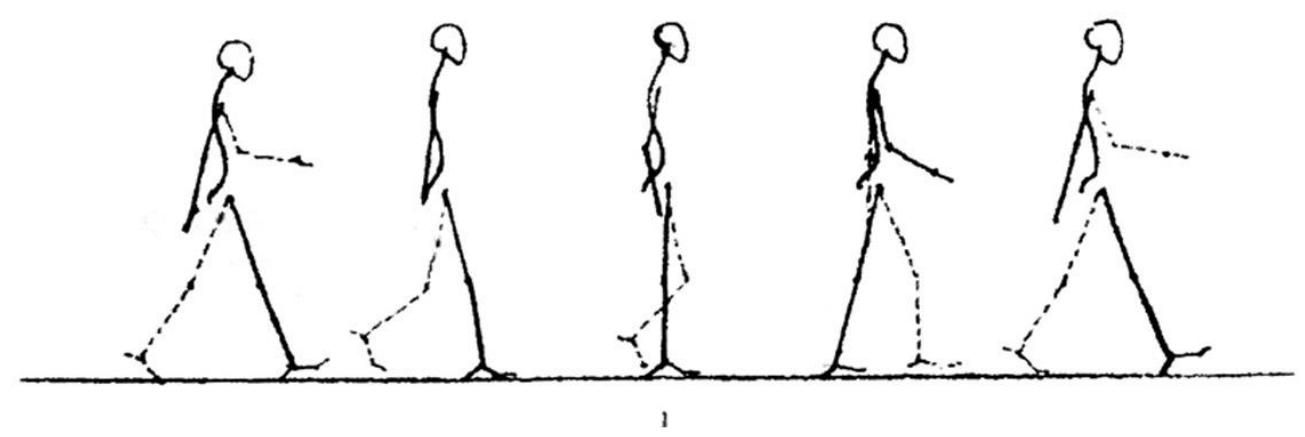

Fig. 4. Human body displacement with alternate support on foots (according to J. Barcsay)

When in motion, the following disbalance arises: projection of center of gravity shifts. Biomechanical peculiarity of motions is that during performance of this motion the support area turns out to be beneath shifted projection of body center of gravity. Due to this fact abovementioned equilibrium is restored.

When moving one foot shifts forward and touches a ground first by heel and then by the whole foot and this way a new support area is created.

The leg, that is put forward, is followed by the body, displacement of which from the earth is continued by a push of other leg left behind. 
In our opinion, precisely this moment is depicted in the picture made by Jean-Etienne Liotard. This fact is testified by following observation. As is seen from the picture (Fig. 1), a certain distance is left by an artist between a foot of the leg put forward and the one left behind that unequivocally confirms that the author of picture reflects shift moment and we can conclude that the mentioned model is depicted when making a move.

Besides, waitress's outstretched arms holding a tray in the picture create large rotation moment that will cause raised requirements to systems of posture regulation and taking a step necessary for restoration of equilibrium (for return of gravity center projection to initial position on support plane) that is actually depicted in the picture.

Thus, on the basis of conducted analysis (waitress's head and body are not disposed on one vertical line, there is shown one moment of alternate motion of legs when walking: certain distance is left between foot of leg put forward and the one left behind, outstretched arms holding a tray in the picture create large rotation moment that causes raised requirements to systems of posture regulation, which confirms dynamic equilibrium of girl's body and therefore the fact that a waitress is depicted by Liotard when in motion. Besides, waitress's body posture, determined by anatomic peculiarities (adequate proportionality of different parts of the body, height, form of chest, facial features etc.) and characteristic harmonious colorful dress are completely reflected in the image of eye-catching girl.

Thus, Jean-Etienne Liotard's picture shows us the expressed dynamic stereotype of a waitress, which along with outer beauty and characteristic harmonious picturesque dress of a chocolate girl reflects genre scene showing corresponding dynamic equilibrium and has positive impact on mood of human at all times and eras.

\section{References / Список литературы}

1. Eliava G. Fundamentals of biomechanics. “Technical University”. Tbilisi, 2001. 3-136 (in Georgian).

2. Svanishvili R., Kakhabrishvili Z. Sports medicine and kinesitherapy. Publishing house "Georgian quality control university". Tbilisi, 2010. 3-576 (in Georgian).

3. Namoradze T., Gabunia D. Human anatomy. Publishing house "Ganatleba (Education)". Tbilisi, 1978. 144148 (in Georgian).

4. Barcsay Jeno. Anatomy for artists. Series "Classical library of the artist". M.: Publishing house EKSMOPress, 2001. 344 (in Russian).

5. Hamm Jack. How to draw human head and figure. Minsk. Publishing house «Попурри», 2007. C. 6-126 (in Russian).

6. Bammes Gottfried. Portrayal of human figure. Second-hand book. M., 1999. 336 (in Russian).

7. Holden Donald. Drawing a human in motion, Publishing house «Феникс». M., 2001. 176 (in Russian).

8. [Electronic resource]. URL: https://en.wikipedia.org/wiki/Biomechanics - This page was last modified on 7 March 2018, at 18:34/ (date of access: 08.06.2018).

9. [Electronic resource]. URL: http://www.dorchesteratheneum.org/page.php?id=674 - This page was last modified on 19 February 2007/ (date of access: 08.06.2018).

10. [Electronic resource]. URL: https://en.wikipedia.org/wiki/The_Chocolate_Girl - This page was last edited on 15 May 2018, at 09:24/ (date of access: 08.06.2018). 